\title{
往来
}

\section{欧州連合における地域政策の展開と 住民参加の課題}

\section{中 道 仁 美}

\section{はじめに}

わが国では戦後経済の不均衡発展の中，様々な過疎対策が講じられてきたに もかかわらず，国土の約半分が過疎地という深刻な状況に至っている。一方， 欧州連合 (以下 $\mathrm{EU}$ ) でも，共同体内の地域格差解消が重視され，様々な地域政 策が進められてきた。EU の地域政策から何を学ぶことができるのか，筆者は， EU の条件不利地域における過疎問題について, 協同組合活動が盛んだったス ウェーデン北部地域と EU 設立当初より地域格差が課題とされたイタリア南部 地域で住民活動の調査を行ってきた。

EU では 2008 年のリーマンショック以降，ギリシャ，アイルランド，スペイ ン，ポルトガルの財政赤字(1), 政府債務残高の割合の高さ，イタリアの政府債務 残高の高さが, EU 統一を摇るがす問題となっている。これらの国々は EU 統一 の課程で地域政策展開の契機となった国々である。本稿では, 地域格差の解消 に向けた EUの取り組み，地域政策の展開を概観し，対象となる地域住民の活 動を検討する。地域の社会的背景により政策成果の発現が異なることを考察し， 財政問題を抱えるわが国地域政策への示唆を考えたい。

$\mathrm{EU}$ 結成の目的は，域内のヒト，モノの自由な往来である。しかし，域内の経 済格差は，この流れを一方的なものにする。EU では，1952 年の欧州石炭鉄鋼 共同体 (以下, ECSC) 発足当初より, 地域間格差の縮小・調和的発展を求めて きた。発足当初, この格差は経済の発展とともに解消するものと考えられたが, インナー 6 と呼ばれる ECSC の原加盟国のイタリアでは, 格差が広がるばかり であった。1973 年のアイルランドの加盟に際して,「構造的および地域的不均 衡」は拡大 EC (EU の前身：欧州共同体)の重要な課題となり，「欧州地域開発 基金 (以下, $\mathrm{ERDF}$ )」が設置され，統一的な地域政策が打ち出される。その後, ギリシャ等発展の遅れた国の加盟により，地域政策はますます重視されるよう になった。

イタリアでは，現在もなお北部地域と南部地域間の経済格差が大きい。この 格差はイタリア近代化の過程で発生した。南部の大土地所有制度（ラティフォ 
ンド）による地主階級の資金・税金，零細農民による安価な労働力が，北部の 工業開発に利用されてきた。第二次世界大戦後の新政府は，この格差を解消す るため，1950 年に復興資金を利用して土地改革に着手し，南部開発を目的とし た南部開発公庫（Cassa per il Mezzogiorno）を設置した。公庫の当初の目的 は農業近代化と農業改革で, 灌溉とインフラ整備(高速道路の延伸)が中心だっ たが，その後，新規投資の $60 \%$, 全投資の $40 \%$ 南部地域に向けたにもかかわ らず，南部の中で地域・階層間格差を広げた(ファビアーニ，1985：243，皆村， $2002: 70)$ 。51 63 年の工業を中心とした高度成長は, 南部から工業が盛んな北 部への労働・資本移動を促し，南北問題は EU 通貨統合を控えたイタリアの大 きな課題となる。

一方, 1995 年に $\mathrm{EU}$ 加盟したスウェーデンは, 1947 年に設置された立地政策 審議会で, 労働力移動の自由を重視しており, 地域間の均衡発展よりも経済的 効率性を優先する立場にあった（穴見，2005：4)。当時，中央集権的な労使交 渉システムの中で，低生産性部門でも高生産性部門でも同一水準の賃金を目指 す連帯賃金が追求され，低生産性部門は自然淘汰され，産業構造全体の効率化 が図られるとされた。産業構造の高度化に伴う失業には 50 年代後半から積極的 労働市場政策が取られ, 職業訓練等のサービスを提供し, 適職を与えようとし た（石原，1995：171）。この戦後復興期の経済成長に伴い，北部地域で人口が 減少し, ストックホルム地域で人口が増加した。これら人口減少地域は中央党, 社会民主党の支持基盤で，産業の地域的配置への政策介入が求められた。

\section{EUにおける地域政策の導入と単一市場への道}

ECSC は 1957 年にローマ条約を締結して，58 年の EC の発足へと展開する が，ローマ条約には「諸国の経済の一体を強化し，多様な地域の間に存在する 格差を縮小することにより，或いは一層恵まれない地域の後進性を緩和するこ とにより，調和した発展を確保することを希求し」の文言が付加されていた。 当時よりイタリアの南北格差が認識されており，58 年のインフラの未整備，低 開発地域の開発などを目的とした欧州投資銀行 (EIB) の設立や，後の地域政策 資金の一角をなす 60 年の欧州社会基金（以下，ESF）の設立にはイタリアの強 い働きかけがあったと言われる(辻，2000：39，44)。ESF は共同市場での流動 性, 特に労働移動の促進を目的としていたので, 地域格差はますます拡大した。 62 年には, 農業部門の自由化を進めるため, 共通農業政策 (以下, CAP) が導 入され，欧州農業指導保証基金 (以下，EAGGF）が設置される。この基金を利 用して， 71 年，農業からの余利労働力を他産業へと移動させるための経済開発 案が出される。

72 年, 最初の統合, アイルランド統合についての会議で,「経済通貨同盟の実 
現を阻害する恐れのある共同体の構造的および地域的不均衡を是正する」とし て，「欧州地域開発基金(以下，ERDF）」の設置が合意され，翌年のトンプソン 報告で初めての地域政策が打ち出される。「統一」と「格差の解消」を目的とし た地域政策で，「追加」「協力」「集中」(2)の 3 原則が出される。助成する地域資 格の客観的な指標が求められ, 平均所得や失業率等が検討され, 資格地域は全 体の $60 \%$, 人口の $40 \%$ に達した。 83 年, 地域政策に新たな提案がなされる。単 発のプロジェクトではなく, 複数のプロジェクトを含んだ，多年度 ( 3 年以上) に亘るプログラムを助成対象とするというものであり，各加盟国が地方自治体 からなる実行主体との協議を行うこと初めて求められた。

81 年のギリシャ, 86 年のスペイン, ポルトガルの加盟で南北格差が重要な課 題として取り上げられる。 87 年の単一欧州議定書（以下，SEA）では地域政策 の基本方針が出され，88 年，ローマ条約 130 条に「経済的および社会的結束」 （SEA 23 条）が追加され,「結束の強化, 特に地域格差の縮小」が求められる。 相対的に貧しい国の増加は，共同体の地域政策の強化を求める勢力の増加も意 味した（辻，2000：83）。5つの対象（目的 ${ }^{(3)}$ ) が設定され，その地域区分につ いて, 目的 1 の貧困地域,「一人当たり平均所得が EC 平均の $75 \%$ 以下の発展の 遅れた地域」など，NUTs (Nomenclature of Territorial Units for Statistics) が決められた。この区分は，その後の EUの基礎的地域区分となるが，イタリ ア南部の多くは，この $75 \%$ 以下の地域として位置づけられる。その結果，イ夕 リアは，89-93 年計画では，目的 1 の基金（全基金の 69.6\%）において，スぺ インに次いで 2 番目に多い基金（19.4\%）を獲得し，94-99 年計画でも，目的 1 の基金（全基金の 68.0\%) で，スペインに次いで 2 番目に多い基金 (15.8\%) を獲得した（辻，2000：102）。

\section{2.コミュニティ・イニシアティブ事業における パートナーシップと LEADER}

88 年改革で「協力」を徹底するために 3 原則に加えて「パートナーシップ」 が打ち出される。 5 つの対象とは別に，委員会が主導して実施する「非割当分」 事業の予算を拡大して「共同主導（コミュニティ・イニシアティブ）」事業が実 施される。各国政府はプログラムの策定と実施に当たり，地方自治体を中心と する「地方の事業実施者」との十分な協議が求められた。ECの地域格差是正政 策は，初めて「地方のため」のみならず，「地方による」政策に転換した（稲本， 2003：32)。88 年改革は, 農村に対して, CAP の変革の必要と，EC 間で経済的 集中をもたらした構造政策の失敗から，構造基金を特に社会経済的弱者に焦点 を当てて介入する方向へと転換した。その結果，コミュニティ・イニシアティ ブが EC 自らの試験的介入として導入され，農村へは，LEADER（Liaison 
Entre Actions de Dèvelopment de l'Economie Rurale：農村経済開発のため の活動の連携）事業が，試験的に導入された。

LEADER では，共同主導という考え方から農村地域の公的機関，民間， NGO/NPO，住民が，地域活動組織（以下，LAG：Local Action Group）を 結成して, 活性化プロジェクトを企画し, EUにその助成を申請するボトムアッ プ・アプローチがとられている（後藤，2004：27）。LEADER は LEADER I, LEADER II，LEADER+と三つの段階に分かれているが，その資金源が EAGGF であることから, 農村開発のへの資金が増大している。EUによる資金 の助成割合は LEADER+では割合でも総額でも増加した。

イタリアの地域政策は, ECSC の発足以降, 常に EU の地域政策と連動してき た。南部は開発の遅れた地域として位置づけられ, 地域政策の導入によって様久 な助成を獲得してきたが，経済格差は縮小しなかった。パットナムは「イタリ アに拝いて市民度が最も低い地域は, 伝統的な南部の村々にほかならない。」現 代，伝統的なイタリア社会の大半の生活は，ヒエラルヒーと搾取が支配してお り，仲間の協力活動を特徵としない」（パットナム，2001：136）と言い，南部 でもカラブリア地域が最も非市民的地域と言っている（パットナム，2001： 181)。LEADER は地域の住民グループの協力が必要とされる活動で，EUの開 発の遅れた地域で多く導入されている。以下では，スウェーデンの地域政策を 考察した後, EU の地域政策の成果を, LEADER 事業を取り入れたイタリア南 部と, EU では貧困地域と位置づけられなかったスウェーデン北部過疎地域に ついて簡単に考察する。

\section{3.スウェーデンの地域政策の道}

スウェーデンでは, 1960 から 65 年にかけて北部地域で仕事が減少し, 年平均 13,350 人規模の人口減少がみられ, 教育・医療などの公的な基本的社会サービ スのための財政基盤が問題となったが，当時の地域政策は，経済成長路線の延 長上の対応であり, 特定の地域に立地する企業への優遇措置であり, 過疎地に 対しては家内産業及び社会サービスへの補助制度が導入された。その後, 石油 危機と賃金コストの上昇による失業の増大と構造的危機により，地域政策補助 金支出が増大し，地域政策の所得再分配，補償的措置といった側面が肥大化し た(穴見, 2005：10)。80 年代, スウェーデンの失業率は戦間期の水準までに達 し, 90 年には金融危機が始まる。90 年に出された新たな地域政策は, 地域開発 手段の北部内陸部への集中, 過疎地・農村の発展手段の改良, 北部のイエムト ランド地域に対する特別支援措置など, 発展の遅れた北部過疎地域に配慮して おり，地域開発により，全国すべての地域で経済成長と福祉の増進，福祉の平 等な配分を促進し，人久の生活水準がどこでも等価であることを保障しょうと 
した。

スウェーデンが EU に加盟する直前の 94 年に出された地域政策提案は, 「全 国すべての地方で生命力のある地域を発展させる」というものであり，当時の 国民運動のスローガン「スウェーデンは生き残る」と連動していた。95 年に出 された地域政策プログラムは，「地域的な均衡は国民経済的な成長を促進する」 とし，地方における下からの投企と活動を奨励し・支援すべきとしており，EU 地域政策と軌を一にするものであった。

スウェーデンは $\mathrm{EU}$ 加盟に当たり, 北部地域の開発のため, 既存の 5 つの目 的に, 人口希薄地域を目的 6 として追加させた。 EU 地域政策 1995-99 年計画 で，スウェーデンに対する構造基金は目的 1 を除くすべての目的に事業総額の 20〜 45\%の基金が割り当てられた。地方開発基金の会計責任を担う中央レベル の地域政策実行組織には，地域政策提案において挙げられた，スウェーデン全 国産業技術開発委員会（NUTEK）がなった。

EU はアジェンダ 2000 で地域社会開発のための構造基金を整理統合した。開 発の遅れた地域への支援を目的とした新たな「目的 1 地域」が設定され，ス ウェーデンでは特に人口希薄な地域, 最北地域とイェムトランドを含む北部地 域の 2 地域を当て，新起業の創出を目指した。これらの地域への投資資金の総 額の $35 \%$ が EU 補助金であった。一方, LEADER は農村開発を目的としている ため, スウェーデンでは農業が盛んな中南部地域に特化している。EU の地域開 発区分 NUTs では，スウェーデン全土が EU 平均所得 $100 \%$ 以上の地域として 位置づけられたが，地域政策では，人口が希薄で生産条件の不利な北部と，人 口が集中している南部や条件の比較的良い中部地域とに分けられてきた。

\section{4.スウェーデン北部イェムトランド県における 地域開発活動と EU 資金}

スウェーデンでは 1974 年に完了したコミューン合併により都市化が進行し， 農村地域では「継続的に続く過疎化と農村地域の格下げに対する抗議運動とし て」集落活性化運動が始まり, 95 年には全農村地域で約 3700 の地域開発グルー プが活動していた（Herlitz，1999：15 頁)。住民組織の多くは協同組合の形式 をとっているが, スウェーデンの協同組合の歴史は 19 世紀まで遡る。1 830 年代 の禁酒運動やその後の自由教会運動は古典的な民衆運動と言われる（秋朝， 2004，64 頁）が，1890 年代にはこれら既存の活動を通して「協同組合は共同集 団や理解者を増強する基盤と意識を獲得した」という（ペストフ 1996， 5 頁）。 1910 年には全部で 5000 を超える組合があり，25 年後には約 3 倍に，1950 年に はその 2 倍になったという（ペストフ，1996，8 頁）が，既存の組合活動が硬 直化するにつれ，1970 年半ばから「ニューウェーブ」協同組合 ${ }^{(4)}$ が現れ始める。 
この新しい組合運動は, 高い経済成長率を続けた 1960 年代に対し, 経済の構造 転換期を迎えて低成長期に入った 1970 年代の経済・財政危機に，伝統的な大衆 社会運動を再活性化することで乗り切ろうとする活動の中で生まれた。

調査事例は北部のイエムトランド県クロコムコミューンのトロングスヴィー ケン地区とオーレコミューンのフーソー集落である ${ }^{(5)}$ 。二つの調査地はともに 高齢化の進んだ条件不利地域であるが，トロングスヴィーケン地区は老朽化し た地域の拠点であるコミュニティセンターの再生を，国，自治体，教会などの 補助のほかに，立地企業も含め地域住民が，資金と労働力を提供することでや り遂げた。この事業は協同組合方式で行われ，施設の維持管理は, 組合 (Trängsviken Bygdegardsförening，以下，コミュニティセンター組合)が担い，作業 は住民の一人が設立した民間会社に委託された。1992 年に竣工したコミュニ ティセンターは地域住民の交流の場所となり，インフォーマルな情報交換や交 流の場として重要な役割を果たしてきた。当地では 1990 年代以降, 商工会 (företagarförening) やコミュニティセンター組合などの「ニューウェーブ」組 合が活動の担い手であり, 1998 年から EU の開発プロジェクトが開始された。 その中心となったのは 2000 年に商工会を解散して設立されたトロングス ヴィーク社 (Trängsviksbolaget $\mathrm{AB}$ ) で，ブロードバンドが達成され，多くの 起業があり, 著名な企業となったものもあった。EU プロジェクトは, 企画・立 案・実施に至るまで，プロジェクトリーダーの力量に大きく依存するが，外部 から専門知識を持ったプロジェクトリーダーが雇用されており, 政策的にイエ ムトランド県に設立された国の地域振興機関や大学等の支援もあった。活動は 全スウェーデンでモデルとして紹介されるようになった。

一方，フーソー集落では，住民のアイデンティティを呼び起こした野外の歴 史劇上演を契機に「ニューウェーブ」組合運動が起こり，一時は識者に「フー ソー組合」と呼ばせたほど多くの事業組合が成立し活性化していた。これら集 落に乱立する「ニューウェーブ」組合を束ねるものとして，1993 年にフーソー 集落自治会が結成され，EU プロジェクトをはじめ，地域開発の企画・実行を 担っている。近年のフーソー集落では事業組合が行き詰まり，過疎化が進んで いるが，地区の活性化のために自治会が中心となって事業を企画・実行に取り 組んでいる。集落の主要な資金の一つは集落が属するカル地区（旧カル村＝カ ル教区）に交付される水力発電の補償金であるが，カル地区内での競争に勝つ ため, 集落でも必要な事業の優先順位を決めて申請している。また，カル地区 として共同申請される EU プロジェクトの集落段階の企画・実行を担っている。 1995-1999 年のカル地区 EU 地域開発プロジェクトでは, 組合活動の発端と なった野外劇に出てくる歴史地区，鉱山跡地の保存活動が採択されており，そ の後の「カル村」プロジェクトでは，鉱山関係の博物館や建物の再生・保存な 
どのプロジェクトが採択されている。しかし，一時は全スウェーデンから人が 来るほど著名であった集落も, 現在は人口減少に歯止めが利かず, 活動は停滞 している。そこには，県都からやや遠く，幹線道路沿いではないなどの地理的 状況に加えて，地方政府の投資がスキーリゾートとして著名な，山を越えた隣 の集落に集中していること,プロジェクトリーダーも自治会の中高年が中心で， 外部の識者がいない, などの課題も見える。

このようにスウェーデンの個別地域では，古くからの協同組合運動が，大衆 運動 (国民運動) とともに根付いており，EUの地域政策のボトムアップ方式に 順応しやすかったし，EU 参加前の地域政策もそのような方向へと誘導してい た。しかし，このようなボトムアップの方式でも，自治体，企業，大学などの 協力，専門のプロジェクトリーダーといった地域支援のあり方がその成功を左 右することも分かった。

\section{5 .イタリア南部カラブリア州における地域開発活動と EU 資金}

イタリアはインナー 6 として, EU 設立当初から $\mathrm{EU}$ の地域政策の発展と同 調してきた。調査地であるカラブリア州は，NUTs で貧困地域として位置づけ られ，多くの資金が投入されてきたが，その成果は十分にみられなかった。そ の原因がパットナムの言うような地域の協力体制のあり方とするなら， LEADER のような地域グループを作って自ら企画立案する方式が有効かもし れない。実際, 最初の試験的な LEADER I を経て, EU 全体に広がった LEADER IIをみると，イタリアはEU の中でスペインに次いで多くの金額が 投下されており，イタリアの中では南部で対象面積も対象人口も多い。カラブ リア州は LEADER＋で, LAG は 9 組織しかないが, 対象面積が全面積の $72 \%$, 対象人口が全人口の $56 \%$ と, 南部 8 州の中でも多いほうに位置する。

イタリアでは 1990 年に新地方自治法, 97 年のバッサニーニ法で地方政府へ の権限委譲が決定され，2001 年の憲法改正により州に組織自治権・立法権，予 算自治権の一部が委譲された。同時期の 84 年, 南部開発機関であった南部開発 公庫（Cassa per il Mezzogiorno）が廃止され，86 年に新たに南部開発庁 (Agensud : Agenzia per la Promozione dello Sviluppo del Mezzogiorno) が 設立されると，南部諸州は開発政策の立案と実施が義務付けられる。首相府の 中には南部局（Dipartimento per il Mezzogiorno）が設置され，国レベルの一 般事業，特別プロジェクト，ECレベルの事業を有機的に管理することとした。 この南部開発庁が 92 年に廃止されると, 南部への EU 資金の流れが停止して, 構造基金が届かなくなる混乱が発生し, 1998 年に新たな南部戦略を担当する部 署として財務省の中に開発・協同政策局 (DPS : Dipartimento per le Politiche di Sviluppo e Coesione) が設置される。ここでの新たな戦略は，地域住民の 
コンセンサスに基づいた方策による南部開発を促すことであった(皆村, 2002 ： $70-71)$ 。

政府主導であった南部開発の責任は自治権の委譲とともに州政府へと移った が, 同時期, $\mathrm{EU}$ でもパートナーシップ原則が導入されるなど, 地域政策のボト ムアップ方式が主流となってくる。EU の 2000-06 年の目的 1 では，国家プロ グラムよりも南部 7 州(6)への資金総額が多く，州が予算的にも地域開発の責任 を担う実態が見える。最大の州は最低の州の 21 倍の資金を獲得しており，州ご との格差が 1994-99 時の 6 倍から広がった。カラブリア州は 4 番目に高い金額 を獲得したが, 最も高い州の約半分でしかない。2000-06 年の LEADER+では LAG 数が減り, 対象面積も対象人口も減ったところが多かったが, カラブリア 州では面積も人口も増加した。これは, 州政府の指導で, LEADER IIから継続 している LAG に対象地域・人口を一部引き継がせるなどの指導を行った結果 である。

調査対象の LAG，ヴァッレ・デル・クロッキオ（Valle del Crocchio，以下 VC) は LEADER I から参加しており，代表，プロジェクトリーダー，その他 合計 5 人が初期から, 会計が 3 年目から参加し, 2000 年から新たに 2 人が加 わった。2000-06 年の参加公共団体はコムーネ 2, 山岳共同体 1 で, その他に 改良組合 1 , 各種団体のうち農業関連団体 4 , その他の団体 1 , 民間企業とし て銀行が加わっている。VCが対象としている地域は, 海から山への広い範囲に 跨るが，山岳地域は過疎化が進行している。過疎地で VC の小起業支援で開業 したもの，事業を拡大したものも少なくない。地域の自然博物館，文化博物館 などの修復再生を手がけ，カラブリア州の地域政策の大きな柱である観光開発 の一翼も担っている。カラブリア州の LAG の特徵であるが, 単なる LEADER 組織から目的 1 のプログラムも担う地域開発組織として成長した。職員は地元 出身で, Uターン者も多く, 初期は不安定だった雇用も, 地域開発組織として 成長することで，新たな雇用さえ生まれた。

\section{6. 地域組織づくりと地域活性化}

EU の地域政策は地域間の格差解消を課題として, 設立当初から取り組まれ てきた長い歴史がある。その経緯をたどると，「地域」の自然的差異に加えて， 社会・文化的な差異から来る経済格差を，EUの統一した政策で取り組んでい る。経済的格差についてはNUTsに，自然的差異や社会的差異は目的 $1 \sim 6$ と いった対象区分に現われていた。一方，国ごとに抱える地域格差は異なり，ガ バナンスも異なる。近年では，地域からのボトムアップ方式が一定の成果を見 せており,地域組織が重要な役割を果たすようになった。EU 資金を利用しなが ら，自国のガバナンスの下で行われる活性化活動は，対象となる地域の組織の 
あり方に依存する。スウェーデンでは協同組合活動にみるように，住民が組織 を作って課題を解消しようとするが，活動への自治体や研究機関，大学等の外 部の支援体制が重要であった。同時に，資金獲得をはじめとして，その成果は 活動の担い手，プロジェクトリーダーに依存するため，人材の確保が要ともな る。一方，イタリアの LAG にみるように，州政府が一部予算自治権をもつこと で，LAG が LEADER 資金だけでなく，その他の EU 資金が獲得できるように なるなど，州独自の組織育成が垣間見られた。

わが国の地域活性化を考えるとき，自治体のボトムアップへの支援や，リー ダー養成・獲得の動きも見られる。しかし，現在ある集落組織のどれを活用す るのが良いのか，新たな活性化組織をつくるのが良いのか。このような研究は 未だ少ない。また，NUTs，目的 $1 \sim 6$ のような地域区分を考えるとき，現在の 中山間地，過疎地といった地域区分で良いのか。ボトムアップの基礎単位の研 究とともに，活動資金確保の研究が必要である。

[注］

(1) 2009 年度の数值は以下の表のとおりである（GDP 比, \%)。

\begin{tabular}{|l|c|c|c|c|c|c|c|}
\hline & アイルランド & ギリシャ & スペイン & ポルトガル & フランス & イタリア & ドイッ \\
\hline 財政赤字 & 14.3 & 13.6 & 11.2 & 9.4 & 7.5 & 5.3 & 3.3 \\
\hline 政府債務残高 & 64.2 & 115.1 & 53.2 & 76.8 & 77.6 & 115.8 & 73.2 \\
\hline
\end{tabular}

出典：田中信世，2010，「欧州金融不安と EU/加盟国の対応」季刊「国際貿易と投資」NO.8, p.6

（2）追加とは，基金から加盟各国の地域助成予算へ追加して資金が提供されることを意味 し，この追加予算分について各国が地域予算を削減することは禁止された。協力とは, 共同体と加盟国が協力して行うことをさし，集中とは，特に困笨した地域に集中して支 出することである。

（3）目的 1 は貧困地域, 目的 2 は衰退工業地域の構造転換及び近代化の促進で, 目的 1 の 対象地域は含まれない。目的 3 は長期的失業の改善, 目的 4 は青年雇用促進, 目的 5 は 農村地域（ $\mathrm{a}$ : 農業構造転換, $\mathrm{b}$ : 観光, 工芸等地域開発) である。

（4）現在の開かれた民主的組合は，既存の伝統的協同組合とは異なるとして，アソシエー ションや協会と訳される場合もある（佐藤，2002：88 頁）ため，このように表現した。

(5) 詳細な考察等は中道他（2007）を参照されたい。

(6) 2000 年から 1 つの州が所得上昇により目的 2 の地域になった。

[参考文献 ]

穴見明，2005，「スウェーデンにおける地域政策の変容(1)」『大東法学』第 46 号 pp 1-35, ファビアーニ グイド, 1985, 『戦後イタリア農業の発展と危機』大明堂

後藤康夫, 2004,「LEADER+見る草の根活動支援と分権化」『農業研究』(日本農業研究所 研究報告） 17 号, pp 21-67 
Herlitz, Ulla, 1999, The Village Action Movement in Sweden - Local Development Employment - Democracy, School of Economics and Commercial Law, Gotheburg University

稲本 守，2003，「欧州連合（EU）の「地域政策」と「マルチガバナンス」『東京水産大 学論集』第 38 号, pp 23-42

石原俊時，1995，「スウェーデン社会民主主義の歴史的展開」西川正雄，松村高夫，石原俊 時『もう一つの選択肢』平凡社, pp 91-190

皆村武一，2002，「イタリア構造的諸改革とユーロへの道(2)」『経済学論集』58 号，p.67-77 中道仁美, 小内純子, 大野晃, 吉澤四郎, 2007, 「条件不利地域における地域開発と住民参 加一スウェーデンの 2 地区の事例から—」『村落社会研究』第 13 巻第 2 号, pp 24-36 パットナム ロバート, 2001, 『哲学する民主主義』, NTT 出版

ペストフ ビクトール，1996，『市場と政治の間で—スウェーデン協同組合論——晃洋 書房

辻 悟一，2000，『EU の地域政策』，世界思想社

佐藤慶幸，2002，『NPO と市民社会』，有斐閣

Ray, Christopher, 2000 年, “The EU LEADER Programme: Rural Development Laboratory", Sosiologia Ruralis 40(2) : pp 163-171

(なかみち ひとみ, 愛媛大学農学部, 農村社会学・女性学) 